Marina I. Orlova • Irena V. Telesh

Nadezhda A. Berezina - Alexander E. Antsulevich

Alexey A. Maximov • Larissa F. Litvinchuk

\title{
Effects of nonindigenous species on diversity and community functioning in the eastern Gulf of Finland (Baltic Sea)
}

Received: 30 June 2005/ Accepted: 13 December 2005/Published online: 8 February 2006

(C) Springer-Verlag and AWI 2006

\begin{abstract}
An increase of xenodiversity in plankton and benthos in the eastern Gulf of Finland was observed from 1998 to 2004. Nonindigenous species account for $4.8 \%$ of all species found and up to $96 \%$ of total biomass. Invasive benthic omnivores, the alien amphipods Gmelinoides fasciatus and Pontogammarus robustoides and the predaceous fish Perccottus glenii with their versatile diets strongly affect the community structure. Invasive sessile seston-feeders that directly (through grazing and water clearance) and indirectly (through recycling of nutrients) interact with other ecosystem components, are mainly represented by the zebra mussel Dreissena polymorpha, which affect the structure of benthic and planktonic communities as well as benthicpelagic coupling. The invasive predatory cladocerans Cercopagis pengoi and Evadne anonyx and larvae of $D$. polymorpha are only temporary components in the zooplankton, which is limiting their overall effect. Alien benthic bioturbators, the polychaetes Marenzelleria neglecta and the oligochaete Tubificoides pseudogaster account for a high proportion of total abundance and biomass but their effects on native species need further research.
\end{abstract}

Communicated by K. Reise

M. I. Orlova $(\bowtie) \cdot$ I. V. Telesh · N. A. Berezina

A. A. Maximov · L. F. Litvinchuk

Laboratory of Freshwater and Experimental Hydrobiology,

Zoological Institute of the Russian Academy for Sciences,

Universitetskaya Emb., 1., 199034 St. Petersburg, Russia

E-mail: marina orlova@rambler.ru

Tel.: + 7-812-32 80211

Fax: + 7-812-3282941

A. E. Antsulevich

Department of Hydrobiology and Ichthyology,

St. Petersburg State University, St. Petersburg, Russia
Keywords Nonindigenous species ' Xenodiversity · Ecosystem functioning - Gulf of Finland - Baltic Sea

\section{Introduction}

The eastern Gulf of Finland (EGOF) is an important part of the Volga-Baltic invasion corridor for freshwater and brackish water organisms. Dominant nonindigenous species (NIS) have originated from the Ponto-Caspian region, from the coastal waters of North America, and from inland waters of eastern Asia (Orlova et al. 1999; Gollasch and Leppäkoski 1999). These species have altered species diversity, community structure and function, and water quality parameters. Key species from the Ponto-Caspian region include the bivalve Dreissena polymorpha (Pallas, 1771) occupying shallow freshwater to oligohaline zones and are found in highest abundance along the northern shore (Antsulevich et al. 2003; Orlova et al. 2004), the predatory cladoceran Cercopagis pengoi (Ostroumov, 1891) widespread in EGOF except for freshwater areas, and the amphipod Pontogammarus robustoides (Sars, 1894). Two key NIS are from North America, the polychaete Marenzelleria neglecta (formerly $M$. viridis, see in Sikorski and Bick 2004) and the North Sea estuarine oligochaete Tubificoides pseudogaster (Dahl, 1960) inhabiting relatively deep regions of EGOF. Species from eastern Asia include the Baikalian amphipod Gmelinoides fasciatus Stebbing, 1899 and the fish Perccottus glenii Dybowsky, 1877 (amur sleeper or rotan) which originates from Amur River. P. glenii occurs in macrophyte vegetation in shallow freshwater. Both, G. fasciatus and P. glenii arrived in EGOF by secondary invasions from continental water bodies, while the others were introduced by shipping. The objective of this paper is to document the present state of xenodiversity in EGOF with results of sampling from 1998 to 2005, and to reveal possible impacts of NIS on the structure and function of selected communities. 


\section{Methods}

Study area

The study area (EGOF) covers the Russian part of the Gulf of Finland $\left(59^{\circ} 40^{\prime}-60^{\circ} 25^{\prime} \mathrm{N}\right.$ latitude and $27^{\circ} 12^{\prime}-$ $30^{\circ} 09^{\prime}$ longitude). For a general description see Davidan and Savchuk (1997). The area may be subdivided into three regions (Fig. 1). The freshwater portion of Neva Bay (I) is separated from the gulf by a storm-surge barrier. The eastern shallow area (II) has a water depth above $30 \mathrm{~m}$ and salinity of $1-2$ at the surface and up to 5-6 PSU at the bottom. The deep-water area (III) generally exceeds $30 \mathrm{~m}$ depth and near-bottom salinity is up to 6-7 PSU. The area is nontidal, but water level fluctuations (about $1 \mathrm{~m}$ ) induced by wind, seiches and changes of the Neva River runoff are common. The near-shore zone from 0 to $7-8 \mathrm{~m}$ does not stratify in summer, but at depths more than $8-10 \mathrm{~m}$ a thermocline is often present. Ice usually covers the sea from December to April. As a result of eutrophication, intensive development of filamentous algae in the littoral zone is a characteristic feature.

\section{Sampling}

Stations sampled in 2004 and 2005 were located in shallow waters along the northern and southern shores and also in offshore areas (Fig. 1). In near-shore waters samples were collected along short transects (2-4 sampling sites) from the "littoral" zone (depth $0.5-2 \mathrm{~m}$ ) to 5-7 $\mathrm{m}$. The principal sampling area was located in the shallow, near-shore region within the freshwater and oligohaline Northeastern waters of the Neva Estuary (region II, Fig. 1). This area covers about $17 \mathrm{~km}$ of the shoreline of the Resort District of St. Petersburg $\left(\mathrm{N} 60^{\circ} 09.32^{\prime}-60^{\circ} 11.37^{\prime} ; \quad\right.$ E29 $\left.38.34^{\prime}-29^{\circ} 54.89^{\prime}\right) \quad$ within which transect 7 (Zelenogorsk) is an ideal location for a detailed study of the quantitative abundance and spatial and temporal variations in populations of key NIS, and for an evaluation of their role in community diversity and function.

Quantitative sampling of benthos in the littoral zone was carried out with a $0.03 \mathrm{~m}^{2}$ cylindrical metal frame of a $0.7 \mathrm{~m}$ height (according to Berezina et al. 2005). At sites with mixed and stony bottoms in the near-shore zone, sampling was carried out using various modifications of SCUBA diving methods (Orlova and Panov 2004). Other sampling procedures for plankton and benthos were standard. Biomass is expressed as fresh weight. Fish were sampled by gillnets of various mesh sizes and by sweep-nets for quantitative investigations. Water samples were collected to determine particulate organic matter (POM) and dissolved inorganic phosphorus (DIP).

To determine feeding patterns (diet), individuals of $P$. robustoides and $G$. fasciatus were collected in the littoral zone in May-June, July-August, and September-October 2004. Perccottus glenii was collected in June 2004 and 2005.

\section{Zebra mussels in benthic-pelagic coupling}

To assess the potential role of D. polymorpha in benthicpelagic coupling, we calculated the rate of DIP excretion, clearance capacity, and rates of consumption and assimilation by the population. Estimates of DIP excretion in zebra mussels are based on body mass $(W)$ in a power function calculated from experiments: $D_{I} P_{\text {ind }}=2.77 W^{0.565}$ (Orlova et al. 2004), extrapolated to population level by the following equation: DIP $_{\text {pop }}=$ $\Sigma \mathrm{DIP}_{\text {cohort }}=\Sigma\left(a W^{b} \cdot N \cdot 24\right)$, given in $\mathrm{mgP} \mathrm{m}{ }^{-2}$ per day, where DIP cohort is the excretion in each size cohort and $W$ is the average body mass for representatives of each cohort ( $\mathrm{g}$ ) and $N$ is number of individuals in the cohort; $24=$ time (hours).

Clearance capacity $S_{\text {pop }}$ is the quantity of seston extracted by the population of zebra mussels from the water column and was calculated as the rate of individual filtration: $F=85.5 \mathrm{~W}^{0.605}$ (Alimov 1981), extrapolated to population level as above and multiplied by POM concentration in the water. Rates of consumption and transformation of POM were calculated with a balance approach (Winberg 1956). The balance equation describes the relationship between food consumption rate $C_{\text {pop }}$ and the rate of food assimilation $A_{\text {pop }}$, and provides a coefficient $u$ of efficiency of food assimilation: $C_{\text {pop }}=A_{\text {pop }} / u$. The assimilated matter $A_{\text {pop }}$ is the sum of respiration $R_{\text {pop }}$ and production $P_{\text {pop }}$. The rate of faeces and pseudofaeces production by molluscs was calculated as $f_{\text {pop }}=C_{\text {pop }}-\left(P_{\text {pop }}+R_{\text {pop }}\right)$ and $\mathrm{pf}_{\text {pop }}=S_{\text {pop }}-C_{\text {pop }}$ both in $\mathrm{g} \mathrm{m}^{-2}$. Respiraton rate was calculated from the power function $R_{\text {ind }}=0.140 \mathrm{~W}^{0.63}$ (Alimov 1981) and then extrapolated to the population.

\section{Results}

Updates to xenodiversity

In 2004-2005 six new NIS were recorded in EGOF: the carnivorous cladoceran Evadne anonyx Sars, 1897, the benthic isopod Jaera sarsi (Valkanov, 1936), the benthic cumacean Stenocuma graciloides (Sars, 1894) (Antsulevich 2005), the bivalve D. rostriformis bugensis (Andrusov, 1897), the Ponto-Caspian amphipod Chaetogammarus warpachowskyi (Sars, 1894), and the South Baltic estuarine nemertean Prostoma puteale (Beauchamp, 1932). We recorded 7 NIS in the littoral zone, 10 in near shore waters in mixed and 11 in sandy bottoms, and only 3 in deeper regions with silt/clay bottoms. For the three portions of the estuary (Fig. 1), the lowest number of NIS was reported from Neva Bay (4 species), and the highest number in the freshwater to oligohaline shallow region II (15 species). We found no 
Fig. 1 Study area. a Position of EGOF and Zooplankton survey in Augusts 1999 and 2004; b EGOF and its counterparts, fairway channel is indicated as dashed line; c principal area; d sampling sites for study of Marenzelleria neglecta. Legend: empty arrows position of transects; circles regular stations

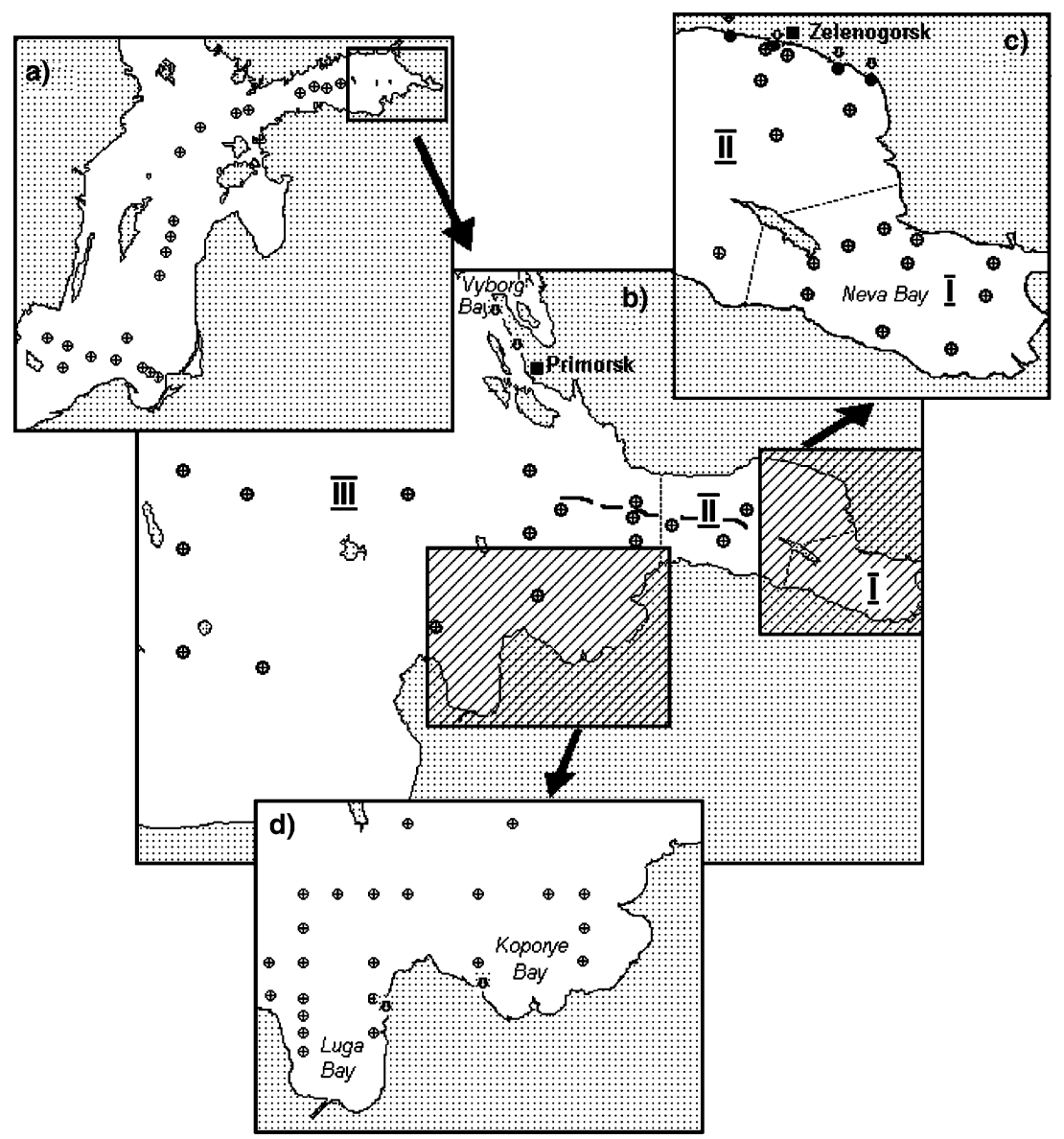

NIS among 147 species of phytoplankton identified in samples collected in 2004. There were 2 NIS among 68 macrophytes (3\%), 7 NIS among 90 zooplankton species $(8 \%$, which includes larvae of benthic NIS), and 18 NIS in 196 benthic invertebrate species $(9 \%)$. Over all in communities, NIS accounted for $4.8 \%$ of total species richness.

Abundance of key NIS and their relation to other species

Amphipods. In summer 2004 maximum biomass of Gmelinoides fasciatus and $P$. robustoides reached $13.2 \mathrm{~g} \mathrm{~m}^{-2}$ and $24.8 \mathrm{~g} \mathrm{~m}^{-2}$, respectively. Together these two invasive gammarids contributed up to $45 \%$ of total biomass in littoral zones of regions I and II. Both amphipods are omnivorous and may affect numbers of small benthic invertebrate prey (Fig. 2). At densities $>5,000$ ind. $\mathrm{m}^{-2}$, there was a negative relationship between amphipods and oligochaetes $(r=-0.33, P<0.25)$ and chironomids $(r=-0.38, P<0.17)$. There was also a significant negative correlation between the biomass of $G$. fasciatus and $P$. robustoides $(r=-0.53, P<0.05)$.

Perccottus glenii was more abundant in 2005 than in 2004 and this was likely related to temperature differences between the 2 years. In the relatively warm sum- mer of 2005, the abundance of this species reached a maximum of 1,550 ind $\mathrm{ha}^{-1}$ and it contributed up to $85 \%$ of total fish abundance in the littoral zone. In the relatively cool summer of 2004, abundance was 450 ind $\mathrm{ha}^{-1}$ and it accounted for $4.5 \%$ of total fish abundance. The average number of fish species collected per catch was 7 in 2004 and but only 4 in 2005 .

Cercopagis pengoi abundance averaged at 60.4 ind $\mathrm{m}^{-3}$ and biomass at $57.34 \mathrm{mg} \mathrm{m}^{-3}$. It contributed up to $33 \%$ of the zooplankton total community biomass in the second half of summers 2004 and 2005. Total zooplankton abundance (excluding protozoans) in the two years ranged from 5,400 to 182,200 ind $\mathrm{m}^{-3}$. The dominant zooplankton groups, which could serve as prey for C. pengoi, were nauplii and copepodites of calanoids (Acartia bifilosa Giesbrecht, 1881, Centropages hamatus Lilljeborg, 1853 and Eurytemora spp.), and small Cladocera. Cercopagis pengoi coexists with the native carnivorous cladocerans Bythotrephes brevimanus Lilljeborg, 1901 and B. cederstroemii Schoedler, 1863 in EGOF. In an area where both cladoceran genera cooccurred in August 2004, Bythotrephes spp. was absent from stations where $C$. pengoi was abundant (Fig. 3).

$D$. polymorpha biomass varied significantly between years $\left(F_{(6,45)}=1.000, P<0.001\right.$; samples collected at Zelenogorsk transect from depth 3 and $5 \mathrm{~m}$ ) over the period of 1998-2005. High biomass (maximum 3,000 g 


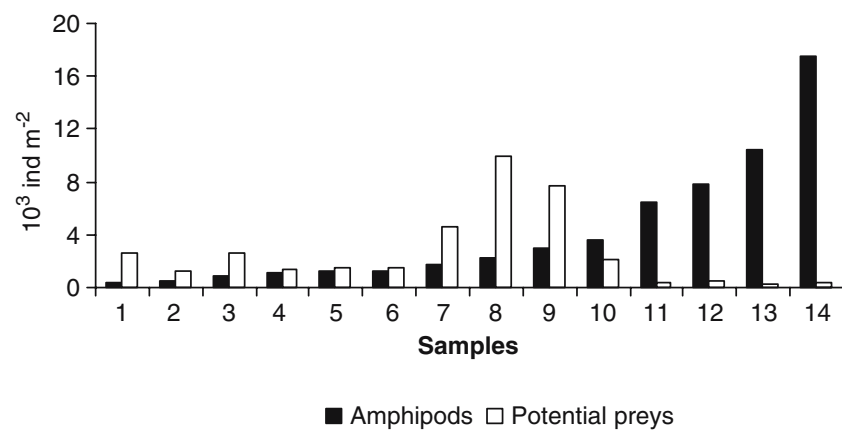

Fig. 2 Abundances of nonindigenous amphipods and their potential prey (benthic oligochaetes and aquatic insects) at 14 locations in the Neva estuary

$\mathrm{m}^{-2}$ ) was observed in 2000-2001 and in 2004-2005. Zebra mussels dominated the benthic communities at stony and mixed bottoms, contributing up to $96 \%$ of total biomass over this period. We found that biomass of associated detritivores was positively $(P<0.05)$ related to Dreissena biomass (Chironomidae: $r=+0.779$ and Oligochaeta: $r=+0.876$ ), while Gastropoda (phytophagous grazers and predators) were unrelated $(r=+0.120)$. Total number of other NIS in these communities was also positively $(P<0.05)$ correlated to Dreissena biomass $(r=+0.716)$ and abundance $(r=+0.705)$, while there was no significant relationship between the number of Ponto-Caspian invaders and Dreissena biomass $(r=+0.430, P<0.13)$ and abundance $(r=+0.438, P<0.10)$.

No more than $70 \%$ of native unionid bivalves collected in EGOF (region II) had attached zebra mussels upon them. Numbers of fouling mussels per basibiont were 2-6 individuals and biomass 3-4.5 g.

Dreissena polymorpha: larvae first appeared in the plankton in late June and remained until late October, 2004. In July 2004 abundance varied from 1 to 108 ind $1^{-1}$, while in 2005 only single individuals were found in several samples through the season.

Annelids: In 2003-2004 Marenzelleria neglecta extended its range eastward to region II, where it was

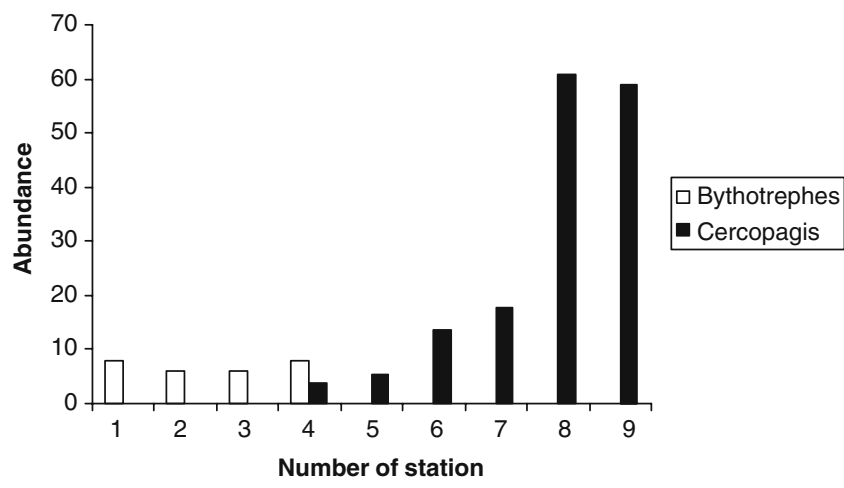

Fig. 3 Abundance (ind. $/ \mathrm{m}^{3}$ ) of Bythotrephes spp. and Cercopagis pengoi in the Gulf of Finland in August 2004 at nine sampling stations found on sandy and clay bottoms. At some sites, $M$. neglecta became the dominant species, forming 70-90\% of total macrozoobenthic biomass. Maximum biomass $\left(30 \mathrm{~g} \mathrm{~m}^{-2}\right)$ was observed in Koporye Bay. We did not find significant negative correlations between $M$. neglecta biomass and any other benthic organisms. Positive correlations $(P<0.05)$ were found with Macoma baltica $(L ., 1758)(r=+0.80)$, Oligochaeta $(r=+0.64)$, Monoporeia affinis (Lindström, 1855) $(r=+0.51)$ and Chironomidae $(r=+0.65)$.

A local population of Tubificoides pseudogaster (about 6,000 ind. $\mathrm{m}^{-2}$ and $5.8 \mathrm{~g} \mathrm{~m}^{-2}$ ) in 2004 was observed at a depth of $36 \mathrm{~m}$ adjacent to fairway channel (Fig. 1b). This oligochaete accounted for about $99 \%$ of total macrofauna abundance and biomass in this area in 2004. The native bottom community at this station was dominated by the amphipod Monoporeia affinis in 2003 before $T$. pseudogaster became established. During the subsequent two years after the invasion $M$. affinis was absent.

Key NIS and intra-population diversity in food spectra

Amphipods: Microscopic analysis of gut content showed that both amphipod species demonstrated high variability in food spectrum as a function of size. Juveniles of $P$. robustoides with body lengths up to $7 \mathrm{~mm}$ fed mainly on detritus, and the proportion of filamentous algae [mainly Cladophora glomerata (Kutz.)] in their diets was low. However, in adults $(8-12.5 \mathrm{~mm})$, the proportion of filamentous algae increased, exceeding $50 \%$ of total food mass. Specimens with body lengths of $13-16 \mathrm{~mm}$ consumed considerably less algae $(5-7 \%)$ as a result of the increasing portion of animal food in their diets. The largest specimens were mainly predators and the proportion of animals in their diet reached $80 \%$ (Fig. 4).

Pecrcottus glenii was studied in 2004 and 2005 years and has also demonstrated variability between ages and sizes in content of stomachs (see Table 1 for more details). All dissected juvenile and adult amur sleepers contained food in their stomachs.

Assessment of potential benthic-pelagic coupling by Dreissena polymorpha

Local zebra mussel populations demonstrated high water clearance capacity $\left(S_{\text {pop }}\right)$ and produce a significant amount of faeces $\left(f_{\text {pop }}\right)$ and pseudofaeces $\left(\mathrm{pf}_{\mathrm{pop}}\right)$. About $50 \%$ of consumed matter $\left(C_{\mathrm{pop}}\right)$ is incorporated by the population $\left(A_{\text {pop }}\right)$ whereas the other $50 \%$ is biodeposited to the sediment as faeces and pseudofaeces (Table 2). Mussels also play a major role in nutrient recycling and clearing water of POM (Table 1). For example, at Zelenogorsk transect the population excreted 5-159 $\mathrm{mg} \mathrm{m}^{-2}$ DIP per day through the 5-year period of observations (Table 2). 


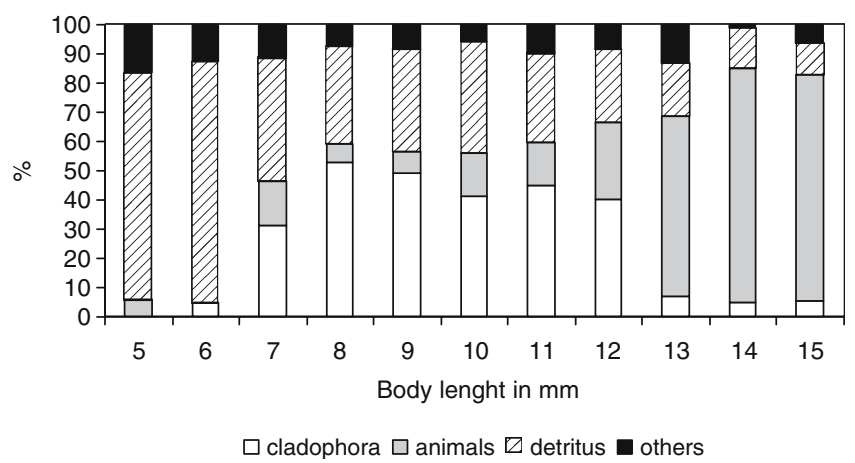

Fig. 4 Body length of the amphipod Pontogammarus robustoides $(N=184)$ and changing weight proportions of food categories

\section{Discussion}

\section{Xenodiversity}

Xenodiversity increased further with a high contribution from Ponto-Caspian species. Evadne anonyx was first recorded in 2004 but may have been overlooked because of its close similarity to the native E. nordmanni Loven, 1836 (Litvinchuk 2005). The single records of Stenocuma graciloides and Dreissena rostriformis bugensis are not yet sufficient to regard these as established populations.

The total number of NIS recorded in 2004 and 2005 was 24 invertebrates, 1 fish and 2 vascular plants. The overall share of $4,8 \%$ NIS may be lower than in other inshore waters (Cohen et al. 2005). However, in EGOF $20 \%$ of NIS have mass occurrences attaining up to $96 \%$ of total biomass. The aquatic ecosystem now differs widely from its "pristine" state. Similar patterns have been observed in other Baltic coastal waters (Kotta et al. 2006) and in the Caspian Sea. The latter water body was dramatically changed after intentionally introduced fishes and invertebrates (Karpevich 1975) and more than 20 other newcomers invaded from the Black Sea since the Volgo-Don channel opened in 1952 (MordukhaiBoltovskoi 1960).

\section{Effects of key NIS}

In the pelagic compartment of the ecosystem, the cladoceran NIS in EGOF is parthenogenetic polyphemids, which exist in the plankton for a rather short time. When abundances are high, these invaders may compete with other planktonic predators. Negative relation between the invader $C$. pengoi and native Bythotrephes spp. may suggest competition for food, while no significant correlations were found between the invading $E$. anonyx and the native E. nordmanni or the invader $C$. pengoi. However, it is expected that food competition between $E$. anonyx and E. nordmanni and predation of $C$. pengoi on $E$. anonyx will arise in the future (Litvinchuk 2005).

At maximum densities $C$. pengoi can eliminate a large portion of the assemblage of smaller zooplankters in the water column (Telesh et al. 2001). In EGOF, this results in a strong correlation $\left(R^{2}=0.82\right)$ between the calculated consumption rates of $C$. pengoi and mean individual body mass of herbivorous cladocerans (Telesh and Ojaveer 2002). C. pengoi affects the size structure of the zooplankton community and modifies the trophic web in the Gulf of Finland by eliminating small planktonic filtrators (Telesh et al. 2000). According to Gorokhova (1998), in the northern Baltic proper nauplii of the copepods Acartia, Eurytemora and Temora, rotifers (Synchaeta), and cladocerans (Evadne) constitute 60, 20 and $20 \%$ of the diet of $C$. pengoi, respectively.

Cercopagis pengoi itself is the preferred prey of the Baltic herring (Antsulevich and Välipäkka 2000) and native mysids (Gorokhova 2005). However, taking into account both the seasonal and interannual dynamics of C. pengoi, this species may affect communities for only a period of some weeks when densities are at a peak.

Three benthic NIS, D. polymorpha, Balanus improvisus and Marenzelleria neglecta, as well as the "native" bivalve Macoma baltica, contribute to zooplankton by supplying larvae in summer and autumn. Based on a survey of Dreissena larvae (Telesh and Orlova 2004), we assume a minor role in changing the microzooplankton because of the short time present, which is similar to the cladoceran NIS.

Table 1 Parameters of dissected individuals $(N=45)$ of Perccottus glenii and content of their stomachs

\begin{tabular}{|c|c|c|c|c|c|}
\hline Age & $\begin{array}{l}\mathrm{L} \\
(\mathrm{mm})\end{array}$ & $\begin{array}{l}\text { Body mass } \\
(\mathrm{g})\end{array}$ & $\begin{array}{l}\mathrm{N} \\
\text { (ind.) }\end{array}$ & $\begin{array}{l}\text { Mass of food } \\
\text { in stomach }(\mathrm{g})\end{array}$ & Content of food with percentage of dominant food item \\
\hline $0+$ & - & - & 25 & $0.001-0.007^{\mathrm{a}}$ & $\begin{array}{l}\text { Zooplankton (close to } 100 \% \text { ): Cladocera (Daphnia sp., Ceriodaphnia sp.), } \\
\text { Copepoda (Mesocyclops leucartii, Eurytemora sp.); swimming larvae } \\
\text { of Chironomidae; small Hydracarina }\end{array}$ \\
\hline $2+$ & $45-60$ & $1.23-3.14$ & 18 & $0.004-0.05$ & $\begin{array}{l}\text { Zoobenthos (close to } 100 \% \text { ): Gastropoda, Chironomidae, Isopoda, } \\
\text { Amphipoda, Odonata, Diptera n/det, Hemiptera (single Corixa } s p \text { ) }\end{array}$ \\
\hline $3+$ & 65 & 7.24 & 1 & 0,065 & $\begin{array}{l}\text { Zoobenthos ( } 99 \% \text { ): Chironomidae, Isopoda, Amphipoda, Odonata; } \\
\text { Zooplankton: Mesocyclops sp., Chydorus spahaericus; remnant of fish } \\
\text { (Cyprinidae n/det, juv.) }\end{array}$ \\
\hline $6+$ & 166 & 92.2 & 1 & 2.710 & Pisces (94\%): Rutilus rutilus; Gastropoda (Cincinna sp) \\
\hline
\end{tabular}

${ }^{\mathrm{a}}$ With mass of stomach 
Table 2 Biotic balance of Dreissena polymorpha populations from Resort District, Zelenogorsk transect

\begin{tabular}{llllllll}
\hline Year & $\begin{array}{l}S_{\text {pop }} \\
\left(\mathrm{g} \mathrm{m}^{-2}\right)\end{array}$ & $\begin{array}{l}P_{\text {pop }} \\
\left(\mathrm{g} \mathrm{m}^{-2}\right)\end{array}$ & $\begin{array}{l}R_{\text {pop }} \\
\left(\mathrm{g} \mathrm{m}^{-2}\right)\end{array}$ & $\begin{array}{l}A_{\text {pop }}=P+R \\
\left(\mathrm{~g} \mathrm{~m}^{-2}\right)\end{array}$ & $\begin{array}{l}C_{\text {pop }}=\mathrm{A}_{\text {pop }} / \mathrm{u} \\
\left(\mathrm{g} \mathrm{m}^{-2}\right)\end{array}$ & $\begin{array}{l}f_{\text {pop }} \\
\left(\mathrm{g} \mathrm{m}^{-2}\right)\end{array}$ & $\begin{array}{l}\mathrm{pf}_{\text {pop }} \\
\left(\mathrm{g} \mathrm{m}^{-2}\right)\end{array}$ \\
\hline 1998 & $106 \pm 54$ & 7.7 & $22.3 \pm 21$ & $30 \pm 21$ & $51 \pm 34$ & $20 \pm 18$ & $65 \pm 52$ \\
2000 & $442 \pm 314$ & $53 \pm 35$ & 155 & $208 \pm 134$ & $347 \pm 314$ & $139 \pm 90$ & $95 \pm 90$ \\
2001 & $343 \pm 126$ & $42 \pm 9$ & $121 \pm 25$ & $163 \pm 34$ & $271 \pm 51$ & $109 \pm 22$ & 72 \\
2002 & $96 \pm 61$ & 15 & $44 \pm 36$ & $59 \pm 52$ & $106 \pm 76$ & $60 \pm 48$ & 0 \\
2004 & $204 \pm 107$ & $47 \pm 12$ & $137 \pm 98$ & $184 \pm 95$ & $324 \pm 151$ & $120 \pm 195$ & 0 \\
\hline
\end{tabular}

In the benthic compartment of the ecosystem, NIS is often a permanent component of communities, and we suggest that they are responsible for many variations in habitat properties and community structure where they have attained dominance. The benthic NIS may be classified into three functional categories based on traits expected to affect ecosystem processes (Hooper et al. 2002): (1) vagile omnivores, (2) sessile seston-feeders and (3) infaunal bioturbators.

Vagile omnivores include the alien amphipods and the amur sleeper. We suggest that their diverse diets allow these species to partition resources and to successfully compete with native species that tend to be more stenophagous. On littoral hard bottoms in Neva Bay (region I), predation by the invasive amphipod $P$. robustoides on other benthic organisms was the main mechanism by which invertebrate density decreased and by which native or earlier established alien species was replaced. At sites where the native Gammarus lacustris and the invasive G. fasciatus were found together, a considerable decline in density and even disappearance of G. lacustris occurred (Berezina 2004). G. fasciatus has a short life cycle and high fecundity that allows it to reach high densities over short periods of time, while $G$. lacustris has a longer life cycle with lower reproductive potential. Also, G. lacustris has low tolerance to wave action (Bekman and Basikalova 1951), which limits its habitat range in the exposed littoral zone of large lakes and estuaries.

G. fasciatus and P. robustoides also play a role in the functioning of littoral communities in EGOF through their grazing activities. According to consumption rates of $P$. robustoides, the dense population found in EGOF littoral zone is able to consume up to $1.9-2.4 \mathrm{gCm}^{-2}$ day $^{-1}$ of algae (Berezina et al. 2005). The average biomass of Cladophora glomerata was $68 \pm 25 \mathrm{gCm}^{-2}$ and primary production $7 \mathrm{gCm}^{-2} \mathrm{day}^{-1}$. Amphipod consumption rates are thus only twofold to threefold lower than C. glomerata production and grazing effects will be significant. In locations with high densities of $P$. robustoides and $G$. fasciatus, these amphipods may actually cause a decline in Cladophora biomass, alleviating an eutrophication effect.

Perccottus glenii either directly (by predation) or indirectly (by food competition) may affect native fishes such as roach and various juveniles. The feeding range of $P$. glenii is exceptionally wide (Bogutskaya and Naseka 2002). Juveniles of $P$. glenii are zooplanktivorous, at 1-3 years $P$. glenii is mainly benthivorous, and when older it is preying on the juveniles of other fish. P. glenii is more resistant to hypoxia, high temperatures, and other abiotic stresses compared to many native fishes (Bogutskaya and Naseka 2002). A higher tolerance may explain the dominance of $P$. glenii in the fish community during the hot summer of 2005 even better than causing a decline in fish diversity by predation.

At sites where the sessile seston-feeder D. polymorpha is abundant, populations may change the trophic web as well as habitat conditions. A calculated energy budget indicates that $50 \%$ of consumed food is assimilated and the other half rejected as faeces and pseudofaeces. Thus, the invasion of zebra mussels in EGOF has formed a fouling assemblage similar to those found in the marine environment (see Dolmer and Frandsen 2002; Thiel and Ullrich 2002). Accumulation of organic material within zebra mussel beds provides food for detritivores species, and may explain the observed correlation between biomass of zebra mussels and detritivores. However, abundance and biomass of these detritivores account for only a small percentage of the total community, probably because faeces and pseudofaeces do not remain for long in the benthos due to high turbulence in the nearshore zone (Orlova et al. 2004). Dreissena polymorpha can facilitate colonization by other invaders. This is shown by positive relationships to the number of other NIS. However, we did not find an "invasion meltdown" effect sensu stricta (as described by Ricciardi 2001). Based on our study, the idea of an "invasion meltdown" not only applies to invaders that originate from the same but also from other regions.

Zebra mussels also play an important role in benthicpelagic coupling through the recycling of nutrients, which may in turn facilitate benthic filamentous green algae (Cladophora glomerata), already promoted by eutrophication (Golubkov et al. 2003). Orlova et al. (2004) compared the contribution from external (input from small brooks and recalculated Neva River input) and internal sources (zebra mussel populations) to the DIP pool along a transect of $17 \mathrm{~km}$ with an area of $4.7 \mathrm{~km}^{2}$ and 6,510 tons of D. polymorpha. It was found that the daily contribution from mussels was of $514 \mathrm{~kg}$ DIP compared to only 7 and $25 \mathrm{~kg}$ DIP from small brooks and the Neva River, respectively. However, the zebra mussels are distributed in patches and the overall effect at the scale of the Gulf of Finland may be small.

It is further suggested that D. polymorpha epizootic growth on unionids in EGOF is not as adverse as reported from North America (Burlakova et al. 2000). This may be explained by the wide availability of hard substrates in the Neva Estuary and by irregular 
recruitment in the $D$. polymorpha populations (Orlova and Panov 2004).

Although the Marenzelleria neglecta has become common and abundant in EGOF, no adverse effects on the native fauna have been observed. However, the role of $M$. neglecta as a dominant species in some shallow areas, combined with its high burrowing activity may transform the benthic community in the future. The lack of the native amphipod Monoporeia affinis in an area with Tubificoides pseudogaster cannot be attributed to the invasion of this oligochaete. No habitat changes were noted in the study area that can sufficiently explain the extinction of the amphipod population (Maximov 2003). Thus, the interaction of $T$. pseudogaster with $M$. affinis, which is a key species in the Baltic benthos, is a field for future research.

Despite high numbers of NIS in EGOF, the effects of NIS on local species and on community structure along with potential impacts on energy exchange between benthic and pelagic compartments of the ecosystem of EGOF is apparently not as dramatic as in the Black and Caspian Seas (see Shiganova et al. 2004a, b). We cannot determine with certainty that current changes in the EGOF ecosystem are caused primarily by NIS. Also, it is difficult to determine whether effects of NIS are negative, positive or neutral. However, two functional groups of benthic invaders, the sessile seston-feeders and mobile omnivores are suggested to play a particularly important role in the utilization and transformation of energy via benthic-pelagic coupling (first group) and in grazing (the second group). They may also change species composition via the "invasion meltdown" effect, which includes trophic, habitat and historical components (first group) and predation and competition (second group).

Acknowledgements The authors acknowledge the support by the MARBEF Network of Excellence "Marine Biodiversity and Ecosystem Functioning" which is funded in the Community's Sixth Framework Programme (contract no. GOCE-CT-2003-505446). This publication is contribution number xxx of MarBEF. The authors acknowledge the Russian "Biodiversity" and "Bioresources" State programs; Governmental contracts \#\# 152 (2004) and 132 (2005); contract with Ministry of Science and Technology of Russian Federation (\#43.073.1.1.2511 in 2004) and in 2005 RFBR (projects \#04-04-49207 and 05-05-65091); LSSP project \#1634.2003.4. The authors thank T. R. Eremina (leader of the project "Baltic Floating University") for running the fieldwork. The experiments comply with the current laws of Russia. We thank Dr. V. N. Nikulina and Mrs. L. V. Zhakova for data on taxonomical composition of plant communities, Dr. V. V. Petryashov for identification of Isopoda. We thank Mr. Thomas Nalepa for comments and language revision of the manuscript and the editor Dr. Karsten Reise for the revision, which significantly improved the MS.

\section{References}

Alimov AF (1981) Functional ecology of freshwater bivalves (in Russian). Nauka Publishers, Leningrad
Antsulevich AE, Välipäkka P (2000) Cercopagis pengoi-new important food object of the Baltic herring in the Gulf of Finland. Int Rev Hydrobiol 85:609-619

Antsulevich AE, Välipäkka P, Vaittinen J (2003) How are the zebra mussels doing in the Gulf of Finland? Proc Eston Acad Sci Biol Ecol 52:268-283

Antsulevich AE (2005) First finding of Cumacea crustaceans in the Gulf of Finland (in Russian). Vestn. St.Petersburg Univ., Ser. 3 (Biol.), 1:84-87

Bekman MY, Basikalova AY (1951) Biology and production capacities of some baikalian and siberian amphipods (in Russian). Proc Probl Thematic Counc 1:62-67

Berezina NA (2004) Causes, peculiarities and consequences of nonindigenous amphipod species dispersal in aquatic ecosystems of Europe (in Russian). In: Alimov AF, Bogutskaya NG (eds.) Biological invasions in aquatic and terrestrial ecosystems. KMK Scientific Press Ltd, Moscow, St- Petersburg, pp 254-268

Berezina NA, Golubkov SM, Gubelit JI (2005) Grazing effects of alien amphipods on macroalgae in the littoral zone of the Neva Estuary (eastern Gulf of Finland, Baltic Sea). Oceanol Hydrobiol Stud 34:63-82

Bogutskaya NG, Naseka AM (2002) Freshwater fishes of Russia fishes about species. Perccottus glenii Dybowski, 1877 at http:// www.zin.ru/animalia/pisces/eng/taxbase_e/species_e/perccottus/ perccottus_e.htm

Burlakova LE, Karatayev AY, Padilla DK 2000. The impact of Dreissena polymorpha (Pallas) invasion on Unionid Bivalves. Int Rev Ges Hydrobiol 5-6:529-543

Cohen AN, Harris LH, Bingham BL, Carlton JT, Chapman JW, Lambert CC, Lambert G, Ljubenkov JC, Murray SN, Rao LC, Reardon K, Schwindt E (2005) Rapid assessment survey for exotic organisms in southern California bays and harbors, and abundance in port and non-port areas. Biol Invasions 7:9951002

Davidan IN, Savchuk OG (eds) (1997) International project "Baltica". Problems of research and mathematical modelling of the Baltic Sea ecosystem. Issue 5, Ecosystem models. Assessment for the modern state of the Gulf of Finland, part 2 (in Russian). Hydrometeisdat Publishers, St-Petersburg, Russia

Dolmer P, Frandsen RP (2002) Evaluation of Danish mussel fishery: suggestions for an ecosystem management approach. Helg Mar Res 56: 13-20

Gollasch S, Leppäkoski E (eds) (1999) Initial risk assessment of alien species in Nordic Coastal Waters. Nord, vol 8

Golubkov SM, Alimov AF, Telesh IV, Anokhina LE, Maximov AA, Nikulina VN, Pavel'eva EB, Panov VE (2003) Functional response of the Neva estuary ecosystem to anthropogenic stress. Oceanologia 45:53-66

Gorokhova E (1998) Zooplankton spatial distribution and potential predation by invertebrate zooplanktivores. 2nd BASYS Annual Science Conference, 23-25.09.1998. Stockholm, Sweden

Gorokhova E (2005) Molecular identification of Cercopagis pengo (Cladocera) in stomach contents of predators In: Exploring diversity of the Baltic sea biota: new tools, results and implications. Book of Abstracts, Helsinki, Finland, 22-24 April, pp 17

Hooper DU, Solan M, Symstad A, Diaz S, Gessner MO, Buchmann N, Degrande V, Grime P, Hulot F, Mermillod-Blondin F, Roy J, Spehn E, van Peer L (2002) Species diversity, functional diversity and ecosystem functioning. In: Loreau $\mathrm{M}$, Naeem S, Inchausti P (eds) Biodiversity and ecosystem functioning. Synthesis and perspectives. Oxford university press, New York, pp 195-281

Karpevich AF (1975) Theory and practice of acclimatisation of aquatic organisms (in Russian). Pishchevaya promyshlennost, Moscow

Kotta J, Kotta I, Simm M, Lankov A, Lauringson V, Pollumäe A, Ojaveer H (2006) Ecological consequences of biological invasions: three invertebrate case studies in the north-eastern Baltic Sea. Helgol Mar Res, 60 (in press) 
Litvinchuk LF (2005) Evadne anonyx Sars, 1897 (Cladocera, Polyphemoidea) - a new representative of the Baltic Sea fauna (in Russian). Biol Inland Waters 1:240-249

Maximov AA (2003) Changes of bottom macrofauna in the eastern Gulf of Finland in 1985-2002. Proc Estonian Acad Sci Biol Ecol 52: 378-393

Mordukhai-Boltovskoi FD (1960) Caspian fauna in Azov and Black Sea basin (in Russian). Publishers of the Academy of Science, Moscow

Orlova MI, Panov VE (2004) Establishment of the zebra mussel, Dreissena polymorpha (Pallas), in the Neva Estuary (Gulf of Finland, Baltic Sea): distribution, population structure and possible impact on local unionid bivalves. Hydrobiologia 514:207-217

Orlova MI, Panov VE, Krylov PI, Telesh IV, Khlebovich VV (1999) Changes in planktonic and benthic communities of the eastern part of the Gulf of Finland concerned with bio-invasions (in Russian). Proc Zool Inst RAS 279:305-325

Orlova M, Golubkov S, Kalinina L, Ignatieva N (2004) Dreissena polymoprha (Bivalvaia: Dreissenidae) in the Neva Estuary (eastern Gulf of Finland, Baltic sea): is it a biofilter or source for pollution?. Mar Pol Bull 49: 196-205

Ricciardi A (2001) Facilitative interactions among aquatic invaders: is an "invasion meltdown" occurring in the Great Lakes?. Can J Fish Aquat Sci 58:2513-2525

Shiganova TA, Dumont HJ, Mikaelyan A, Glazov DM, Bulgakova YV, Musaeva EI, Sorokin PY, Pautova LA, Mirzoyan ZA, Studenikina EI (2004a) Interactions between the invading ctenofores Mnemiopsis leidyi (A. Agassiz) and Beroe ovata Mayer 1912, and their influence on the pelagic ecosystem of the Northeast Black Sea. In: Dumont et al (ed) Aquatic invasions in the Black, Caspian and Mediterranean Seas. Kluwer, Dordrecht, pp 33-70

Shiganova TA, Dumont HJ, Sokolsky AF, Kamakin AM, Tinenkova D, Kurasheva EK (2004b) Population dynamics of Mnemiopsis leidyi in the Caspian ecosystem. In: Dumont et al (ed) Aquatic invasions in the Black, Caspian and Mediterranean Seas. Kluwer, Dordrecht, pp 71-111

Sikorski A, Bick A (2004) Revision of the genus Marenzelleria Sarsia 89:253-257

Telesh IV, Ojaveer H (2002) The predatory water flea Cercopagis pengoi in the Baltic Sea: invasion history, distribution and implications to ecosystem dynamics. In: Leppäkoski E., Gollasch S., Olenin S. (eds) Invasive aquatic species of Europe. Distribution, impacts and management. Kluwer, Dordrecht, $\mathrm{p}$ $62-65$

Telesh IV, Orlova MI (2004) Relationships between invasive species Dreissena polymoprha (Pallas) and microzooplankton in coastal waters of the Neva River estuary (Gulf of Finland the Blatic sea). In: Alimov AF, Bogutskaya NG (eds) Biological invasions in aquatic and terrestrial ecosystems (in Russian). KMK Scientific Press Ltd, Moscow, pp 268-275

Telesh IV, Litvinchuk LF, Bolshagin PV, Krylov PI, Panov VE (2000) Peculiarities of biology of the Ponto-Caspian species Cercopagis pengoi (Crustacea: Onychopoda) in the Baltic Sea. In: Matishov GG (ed) Species introducers in the European Seas in Russia (in Russian). Academic Science Press, Apatity, pp $130-151$

Telesh IV, Bolshagin PV, Panov VE (2001) Quantitative estimation of the impact of the alien species Cercopagis pengoi (Crustacea: Onychopoda) on the structure and functioning of plankton community in the Gulf of Finland, Baltic Sea. Repts Rus Acad Sci Biol Sci 377:157-159

Thiel M, Ullrich N (2002) Hard rock versus soft bottom: the fauna associated with intertidal mussel beds on hard bottoms along the coast of Chile, and considerations on the functional role of mussel beds. Helg Mar Res 56:21-30

Winberg GG (1956) Intensity of metabolism and food consumption in fishes (in Russian). Minsk State Belarus university publishers, Minsk 